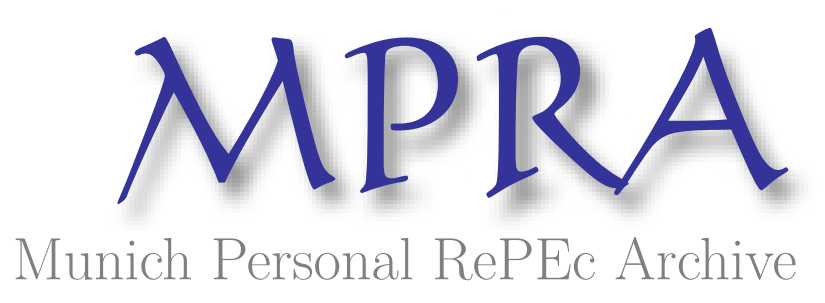

\title{
Success Factors in Mobile Viral Marketing: A Multi-Case Study Approach
}

\author{
Pousttchi, Key and Wiedemann, Dietmar Georg \\ University of Augsburg
}

2007

Online at https://mpra.ub.uni-muenchen.de/5736/

MPRA Paper No. 5736, posted 14 Nov 2007 06:00 UTC 


\title{
Success Factors in Mobile Viral Marketing: A Multi-Case Study Approach
}

\author{
Key Pousttchi, Dietmar G. Wiedemann \\ Mobile Commerce Working Group, Chair of Business Informatics and \\ Systems Engineering, University of Augsburg, 86135 Augsburg, Germany \\ \{key.pousttchi,dietmar.wiedemann\}@wi-mobile.de
}

\begin{abstract}
A prior study showed that mobile viral marketing is an important issue of mobile marketing. Using a multicase study research approach, we introduce a typology of four standard types of mobile viral marketing and extract eight success factors for this new form of marketing. As a final step, we structure the relationship between both, showing success factors' significance in different standard types and deriving a success factor framework. We conclude with a consideration of research implications.
\end{abstract}

\section{Introduction}

In a prior study almost 70 per cent of 44 mobile marketing experts stated that mobile viral marketing is an important issue of mobile marketing. The respondents confirmed that personal messages sent by friends gain more credibility than those coming directly from the self-interested advertiser. In addition, people who get the initial message from a familiar recommender participate more frequently in a campaign as initial contacts. [28] Hence, viral elements help to expand significantly the number of recipients and increase the impact of the campaign at low company expense. Like its counterpart on the stationary Internet, termed in this paper as electronic viral marketing, mobile viral marketing is based on word-of-mouth (WOM) and can be understood as a distribution and communication concept [10]. The term "viral marketing" uses the exponential diffusion of an epidemic as a metaphor for the exponential diffusion of information about products or of the products themselves by "infected" individuals [10] in this type of mobile marketing. Since an epidemic may be local and can be global the metaphor may be used regardless of the scale of diffusion which is achieved with a mobile viral marketing strategy.

Following these considerations we define mobile viral marketing as a concept for distribution or communication that relies on customers to transmit content via mobile communication techniques and mobile devices to other potential customers in their social sphere and to animate these contacts to also transmit the content. We define such content as mobile viral content; it comprises mobile products, services, or ads. Also Wireless Application Protocol (WAP) Push and Uniform Resource Locator (URL) fall in this category. Individuals transmitting mobile viral content are termed communicators; individuals receiving mobile viral content are termed recipients.

To better understand why and how mobile viral marketing can be effective, practitioners must be aware of the phenomenon's characteristics and the factors underlying success or failure. Only then they can provide customers with content that enables viral diffusion on the mobile channel. For scholars our goal is to provide useful starting points and impetus for further research. Thus, the outcome of the paper is a typology of four standard types and a set of eight success factors in mobile viral marketing. With clear reflections of success factors' significance in different standard types we structure the relationship between both and develop a success factor framework. The results are based on an analysis of 34 case studies.

The paper is organized as follows: In Section 2, we provide a literature review that focuses on mobile viral marketing and typologies in electronic viral marketing. Section 3 offers the details of the method used in this paper. In Section 4, we present and discuss our results. Finally, we conclude with a consideration of research implications in Section 5.

\section{Literature review}

While scholars have provided a sizeable body of research on mobile marketing and its success factors [15], research explicitly focusing on mobile viral marketing has received less attention [18]. The belowmentioned studies allude to the topic only marginally (mainly by one or two survey questions) and focus basically on other aspects of mobile marketing. However, they provide some interesting findings. 
Barwise and Strong found out in a trial, that 17 per cent forwarded especially entertaining or informative mobile ads $(n=500)$ [3]. According to a survey of Skopos, 30 per cent said a friend's recommendation would convince them to download a mobile application $(n=2,500)[12]$. A study published by Intuitive Media and New Media Age stated, 29 per cent would share and 45 per cent would intend to share music with friends via Bluetooth $(n=1,477)$ [11]. These results illustrate the potential of mobile viral marketing for distribution and communication purposes.

Analyzing mobile marketing from a theoretical viewpoint, Pousttchi and Wiedemann defined six mobile marketing objectives [21] - one of these is motivating mobile viral marketing. They also developed a conceptual framework that provides an insight into achieving these objectives with different forms of campaigns.

In terms of academic research, the exploratory study [27] represents a first step in filling the aforementioned void in mobile marketing research by focusing exclusively on mobile viral marketing. Based on a literature review, relevant characteristics of mobile viral marketing were identified and classified within a morphological box $[29]^{1}$ and four standard types were proposed.

In the area of electronic viral marketing, some authors provided typologies. A popular typology is between high and low integration strategies varying in the degree of requiring the customer's activity in passing on the "virus" (e.g., [10]). Subramani and Rajagopalan added a second factor, the level of network externalities [24]. This typology is suitable for an extension on mobile viral marketing as will be shown in Section 4.1.

\section{Method}

This contribution completes and significantly extends the results of [27]. For both papers we rely on the case study approach (e.g., [8]). 34 accurately described case studies ${ }^{2}$ were analyzed according to the process described in [8] in order to derive standard types of mobile viral marketing. Conducting withincase analysis detected two groups of case studies. While case studies being mobile services with network

\footnotetext{
1 The characteristics of the morphological box were participant, motivation of communicator, role of communicator in persuasion, added value for recipient, content type, content generation, impact, level of network externalities, cost of communicator or recipient, recommendation type, mobile network type, and enabling technology. For the respective instances, see [Wi07].

${ }^{2}$ For a complete list of the case studies we refer to [Wi07]. The case studies were found through a web content analysis. A list of typical case studies used as examples in this paper is provided in Table 2 .
}

externalities represent the distribution concept of mobile viral marketing, in contrast, case studies being mobile marketing campaigns represent the communication concept. Further, conducting crosscase search revealed typical patterns composed of the instances of two characteristics. This led to a further distinction at a lower level that we term the standard type level. Afterwards we derived the success factors of mobile viral marketing and link them to the standard types. Especially, we analyzed how the viral diffusion in each case study resulted. Afterwards, we compared the results with electronic viral marketing literature to get more and deeper insight in our findings and achieve stronger internal validity. Finally, we structured the relationship between the success factors and standard types using a matrix representing the Cartesian product in order to develop a success factor framework.

\section{Results and discussion}

\subsection{Mobile viral marketing standard types}

As stated above, the analysis of case studies exposed typical patterns consisting of the instances of two characteristics. The first characteristic - the role of communicator in persuasion - differs between the attempt of communicators to influence is passive or active persuasive [24]. Active viral marketing is closely associated with traditional WOM because the communicator is personally involved in the process of acquiring new customers. In contrast, in passive viral marketing, the request to forward the content is integrated into the process, e.g., by an additional message that is sent by the marketer. The second characteristic - the level of network externalities differs between high and low. Network externalities describe the fact that "the value of a unit of the good increases with the expected number of units to be sold" [6, p. 678] or used [13].

Together, these two characteristics highlight four quadrants that are termed as mobile viral marketing standard types and shown in Table 1. While comparing the results with literature, we recognized similarities of the emergent types to Subramani and Rajagopalan [24] who provided four quadrants related to electronic viral marketing ${ }^{3}$. Therefore, we use their naming: (1) Motivated Evangelism; (2) Signaling Use, Group Membership; (3) Targeted Recommendation; and (4) Awareness Creation, Benefits Signaling. Whereas the

\footnotetext{
${ }^{3}$ The authors showed that the types provide insights into the nature of influence and the importance of characteristics of communicators and recipients [SR03]. There is evidence to suggest that these issues are important for mobile viral marketing as well. Thus we will explore these issues in future papers.
} 
standard types represent different major concepts, they are not totally disjoint: any of the current mobile viral marketing strategies can be classified into (at least) one standard type, but a single mobile viral marketing strategy may use more than one standard type.

Table 1. Mobile viral marketing standard types

\begin{tabular}{|c|c|c|c|c|}
\hline \multirow{2}{*}{ 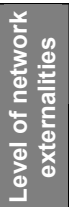 } & ․ㅗำ & $\begin{array}{c}\text { Motivated } \\
\text { Evangelism }\end{array}$ & $\begin{array}{l}\text { Signaling Use, } \\
\text { Group } \\
\text { Membership }\end{array}$ & $\begin{array}{l}\text { Distribution } \\
\text { concept }\end{array}$ \\
\hline & 3. & $\begin{array}{c}\text { Targeted } \\
\text { Recommendation }\end{array}$ & $\begin{array}{c}\text { Awareness } \\
\text { Creation, Benefits } \\
\text { Signaling }\end{array}$ & \multirow[t]{2}{*}{$\begin{array}{l}\text { Communicat } \\
\text { ion concept }\end{array}$} \\
\hline & & Active & Passive & \\
\hline
\end{tabular}

Motivated Evangelism. This standard type is characterized by an active role of communicators in influencing recipients and by high network externalities. Communication services like the iconbased mobile messaging application Zlango, locationbased friend finders like Mobiloco, or mobile communities like Peperonity.com are examples. The viral effect in this standard type occurs as communicators as well as recipients need to use the service to benefit from the usage. This benefit motivates early adopters to actively persuade recipients to also try the good so that they both can use it. Thus, this type demands the proactive participation of communicators in acquiring new users. Network externalities are high as both and others users benefit from a wider diffusion of the service. In the presented examples, the application can be used to send messages to a wider audience, to find more friends, or to communicate with more people. Subramani and Rajagopalan stated that it is conceivable that each marketer's dream comes true and each new recipient turns into an evangelist for the good inside his or her circle of friends, and the installed base grows exponentially [24]. However, rates of growth like in their Motivated Evangelism examples (i.e., ICQ with 100,000 new users every day) are even seldom on the stationary Internet.

Signaling Use, Group Membership. This standard type is characterized by a passive role of communicators in influencing recipients and by high network externalities. Examples include the use of specific kinds of mobile network products and services, e.g., mobile payment procedures like the German Paybox solution used in the customer-tocustomer scenario. When a user (i.e., the communicator) sent money to an unregistered user (i.e., the recipient), the later was able to receive the money only by signing up for the mobile payment procedures. The communicators' "recommendation" is passive as the recipients are informed by text messages (Short Message Services, SMS) from the mobile payment service provider and has the "effect of signaling the user's membership in a group with desirable attributes" [24, p. 304]. There are positive network externalities associated with usage, as all users would benefit from the broader installed base of the mobile payment procedure enabled by wider adoption. Since mobile devices will have more computing power in the future the same process is likely to happen with mobile file compression utilities or proprietary document formats (like Winzip, PDF, or Real Media known from the personal computer world) when WAP Push is used to spread such content and the recipient is informed of the need to download a software component to deal with the content.

Targeted Recommendation. This standard type is characterized by an active role of communicators in influencing recipients and by low network externalities. A send-to-a-friend-option is a typical instance. This is a function of Java applications or WAP sites enabling the communicators to send directly an SMS, WAP Push, or email to recipients by at least entering the recipients' mobile telephone number (Mobile Subscriber ISDN, MSISDN) or email address. A less sophisticated solution includes added requests to mobile ads like "send this to a friend". Also contests that require the active participation of other people fall into this type. Further examples are mobile short films (micro movies) that are downloaded from special portals on the stationary Internet or from the mobile Internet. Typically, Bluetooth is used to transmit the content since data transmission cost are high and multimedia messages (Multimedia Message Service, MMS) are limited to a certain data volume by most mobile operators. In this standard type, network externalities are low as there is typically no change of benefit for customers when communicators forward the mobile viral content to other recipients. A crucial principle of (electronic and mobile) viral marketing is that people are linked with others who are similar to themselves which is called by Rosen as homophily [22]. Typically, the communicator can roughly predict the recipient's interests and preferences based on private information. Thus, in particular, Targeted Recommendation shows great promise for spreading specific product information within a target group which could be extremely difficult to reach otherwise.

\subsection{Success factors of mobile viral marketing}

Some critics of viral marketing argue that successful viral marketing is rather the outcome of fortunate circumstances and variables marketers cannot 
control than the outcome of a brilliant strategy [9]. However, case study research and literature review indicate the existence of some clearly identifiable key elements assuring the success of mobile viral marketing. We list these success factors under eight headings: (1) perceived usefulness by recipient; (2) reward for communicator; (3) perceived ease of use; (4) free mobile viral content; (5) initial contacts; (6) first mover's advantage; (7) critical mass; and (8) scalability. No claim is made that the success factors presented here are exhaustive. Further mobile marketing researchers should add to or modify the ideas presented here.

Perceived usefulness by recipient. Considering both concepts of mobile viral marketing, customers will only accept new services or mobile marketing, if they obtain a relative advantage (e.g., [23]) or an added value (e.g., [1]). Consequently, the content should contain a real value [10] which is perceived as useful by the recipient. Perceived usefulness by recipient describes the benefit for recipients while getting the mobile viral content. Whereas in Motivated Evangelism and Signaling Use, Group Membership the value is typically a service, in Target Recommendation the value is typically a product or service information (see for an example the Adidas campaign presented in Table 2). Also corporate prizes in (viral) contests that require the participation of other people can attach value. The mobile viral marketing campaign for the movie Mona Lisa Smile (Columbia Tristar Film) is a good example. Four people could win a group cinema ticket when the communicator persuaded three recipients to answer an SMS that was sent from the brand website by the communicator. Although we found no such case study up to date, the value in Targeted Recommendation could consist of a monetary incentive as well. For instance, a mobile coupon can be forwarded. In standard type Awareness Creation, Benefits Signaling, the value is typically entertainment (for an example, see the L'Oréal campaign presented in Table 2). Commonly used applications are greeting cards that fulfill the desire to communicate with peers in a funny personal way and provides added value for both - communicators and recipients.

Reward for communicator. Rewards have been demonstrated to be a major driver of human behavior in general (e.g., [14]) and are considered by reward beneficiary (in our case the communicator) as a sign of appreciation of his or her own behavior by the reward giver (in our case the marketer). Thus, a reward for the communicator may motivate to forward the mobile viral content. In Motivated Evangelism and Signaling Use, Group Membership communicators may get a reward for every new user. In Targeted Recommendation, reward for the transmission may be an effective strategy to enhance the extrinsic motivation of communicators. In the Mona Lisa Smile case study, the communicator got an exclusive ring tone, when three recipients were persuaded to participate in the contest. In Awareness Creation, Benefits Signaling, reward will be possible, e.g., if a communicator sends personalized SMS to a certain amount of other people via a brand website. In a campaign for the video game Resident Evil each communicator got points for forwarding an SMS from the brand web site. The more points he or she scored, the better was the prize he or she could win. [4] However, the success of mobile viral marketing hinges on the strong need of communicators to be perceived as persons communicating with peers in a funny way, well informed helper, or expert of a particular topic in their social network and not perceived as a paid agent of a marketer. Mobile viral marketing strategies that make too overt attempts to designate communicators to promote products and services are likely to upset the balance and reduce the effectiveness of the approach. Companies would do well to reflect on this very carefully.

Perceived ease of use. According to Wilson, "viruses" only spread when they are easy to transmit [26]. Thus, like with a disease the probability of a wider diffusion of the virus increases with its easy transmission, in mobile viral marketing, the probability of a wider diffusion of the content increases with its easy transmission as well. According to Davis [5], we define perceived ease of use as the degree to which a person believes that receiving and forwarding mobile viral content would be free of effort. While most case studies used (for most people) simple forwarding mechanism like sending SMS and MMS or using IVR (typically in Awareness Creation, Benefits Signaling), perceived ease of use is relevant at other instances. Generally, in Motivated Evangelism and Signaling Use, Group Membership the implementation process of mobile services has to be convenient to avoid a breakup during the adoption process that is described by Rogers [23]. In Targeted Recommendation, ease of use will be of importance, if Java- or WAP-based sendto-a-friend options are used. Due to limitations of mobile devices (e.g., small screen and key pad) typing a name, MSISDN, or email address may be difficult for unexercised people and typos may occur. In this context, a welcome improvement is the JSR 75 (Java Specification Request) that defines an API (application programming interface) that gives J2ME (Java 2 Micro Edition) enabled devices access to contact data stored in the address book. Thus, future Java-based send-to-afriend options will operate like forwarding an SMS or MMS as contact data can be easily selected. In case of 
a mobile short film, fast transmission is required. Thus, data volume should be little.

Free mobile viral content. In the majority of case studies, communicators had to pay only transmission cost and the mobile viral content per se was for free. In certain cases a premium rate of $€ 0.49$ was charged; thus, the user financed the answer of the marketer. In the context of electronic viral marketing, Helm argued that the content should be offered for free. The specific cost structure of digital products (with the marginal cost approaching zero) favors this gratis distribution [10]. We argue that this strategy should be applied in mobile viral marketing as well, because users were accustomed to a "for free mentality" due to their Internet usage as on the Internet most content is for free. Additionally, this assumption is based on Pagani who found out that price is the third important factor influencing mobile services adoption (after perceived usefulness and ease of use) [19]. Using mobile viral marketing as communication concept, such sponsoring models are problem-free, because receiving advertising is typically for free. However, this strategy poses a problem with using mobile viral marketing as distribution concept, since service providers have to find sustainable business models. Answers may be that the free service aims at the use of a further service offer with costs or the built up customer base is used for advertising purposes.

Initial contacts. Initial contacts are the first "generation" of communicators. Adapting the viral participant typology of Phelps et al. [20] to mobile viral marketing, we refer to mobile viral mavens as customers who receive and forward mobile viral content frequently; we refer to mobile infrequent senders as customers who are less avid about sending content. Consequently, identifying and addressing mobile viral mavens as initial contacts is an important success factor in all standard types. Helm suggested that the initial contacts should be chosen very carefully and that Internet users that foster intense contact to other users (e.g. students) are especially interesting [10]. In the context of mobile viral marketing, marketers can brief initial contacts on the content at high-traffic connection points on the stationary or mobile Internet using Web or mobile advertising banners. This strategy was used by T-Mobile and tele.ring in campaigns for 2006 FIFA World Cup WAP portals [16]. However, this is rather an undirected strategy as the target group is typically not the whole group of Internet or mobile phone users. Thus, we consider it best when marketers inform the initial contacts by a mobile marketing push campaign. For instance, in the Mona Lisa Smile case study, women in the age between 17 and 25 listed in the mobile marketing service provider's data base were informed about the campaign by using push SMS.

First-mover's advantage. Helm stated that at least in the initial phases, the content should have no competitors in the perception of the customers [10]. This requirement is typically important for Motivated Evangelism and Signaling Use, Group Membership. As network externalities are high in these standard types, we can apply Metcalfe's law that suggests that the overall value of a network increases with the square of the number of users [25]. Thus, a first-mover's advantage can increase exponentially when he is able to effectively dominate a network early on. For instance, it is very likely that Paybox gained its customer base of 850.000 users till 2003, because of their first-mover's advantage in this early stage of mobile payment.

Critical mass. Products and services with network externalities are often indicated by the existence of a critical mass point [7]. The critical mass is defined as the minimal number of adopters of an innovation for the further rate of adoption to be self-sustaining (e.g., [23]). Thus, the critical mass concept means that "an equilibrium market for the good does not exist unless the installed base is greater that a minimum level" [7, p. 31]. In the context of mobile viral marketing, reaching the critical mass is crucial for Motivated Evangelism and Signaling Use, Group Membership as the level of network externalities is high in these types in opposite to Targeted Recommendation and Awareness Creation, Benefits Signaling. However, as Mahler and Rogers argued, especially telecommunications innovations with strong network externalities which are highly interactive in nature and which are characterized by direct network externalities "should be expected to have a more pronounced critical mass in their rate of adoption" [17, p. 720]. Thus, this success factor is especially crucial for services contained in Motivated Evangelism. In the Zlango example (Table 2), the critical mass concept would mean that a customer is not interested in adopting the application because the installed base is too small, i.e., he cannot send Zlango messages to any other mobile phone users like an SMS, and the installed base is too small because an insufficiently small number of customers have adopted Zlango. This mechanism is called the chicken and the egg paradox that logically arises in such markets (e.g., [7]).

Scalability. Wilson argued that a viral model has to incorporate scalability [26]. Scalability refers to the "ability of a system to accommodate an increasing number of elements or objects, to process growing

\footnotetext{
${ }^{4}$ Goods showing direct network externalities do not have any utility per se and are only useful if others also use this good (e.g., [Ec96])
} 
volumes of work gracefully, and/or to be to enlargement" [2, p. 195]. Scalability can be a very important feature for both - user and service provider. For an user, it means he or she can invest in a service or product with confidence that it will work for the future - irrespective of the number of other users. For a service provider, it implies that the underlying business model offers the potential for economic growth. In particular, this is important for Motivated Evangelism and Signaling Use, Group Membership. For instance, Zlango and Paybox (Table 2) require their own infrastructure to transmit the messages and process the payments respectively. If the strategy is very successful, capacity of underlying infrastructure must be expanded very quickly to assure fast response time and overall performance of the system or the rapid growth will die.

The case study research and literature review revealed eight success factors of mobile viral marketing and indicated that the significance of success factors varies in different standard types. This is shown by the success factor framework in Table 3.

Table 3. Success factor framework

\begin{tabular}{|c|c|c|c|c|c|c|c|c|}
\hline \multirow[b]{2}{*}{ Type } & \multicolumn{8}{|c|}{ Success factor } \\
\hline & 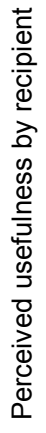 & 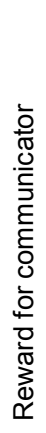 & 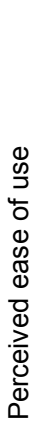 & 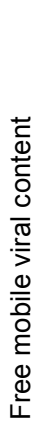 & 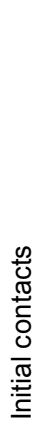 & 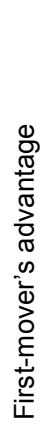 & 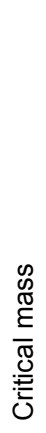 & $\frac{\vec{t}}{\frac{\overrightarrow{0}}{\overline{0}}}$ \\
\hline $\begin{array}{l}\text { Motivated } \\
\text { Evangelism }\end{array}$ & $X$ & $X$ & $\mathrm{X}$ & $x$ & $\mathrm{X}$ & $x$ & $X$ & $x$ \\
\hline $\begin{array}{l}\text { Signaling Use, Group } \\
\text { Membership }\end{array}$ & $x$ & $X$ & $X$ & $x$ & $X$ & $X$ & $X$ & $x$ \\
\hline $\begin{array}{l}\text { Targeted } \\
\text { Recommendation }\end{array}$ & $x$ & $X$ & $x$ & $x$ & $\mathrm{X}$ & & & \\
\hline $\begin{array}{l}\text { Awareness Creation, } \\
\text { Benefits Signaling }\end{array}$ & $\mathrm{x}$ & $X$ & $\mathrm{X}$ & $x$ & $X$ & & & \\
\hline
\end{tabular}

There are narrow differences with the success factors perceived usefulness by recipient, reward for communicator, perceived ease of use, free mobile viral content, and initial contacts. However, first mover's advantage, critical mass, and scalability are important for Motivated Evangelism and Signaling Use, Group Membership as the level of network externalities is high in these types.

\section{Conclusion and future research}

Starting point for our consideration was the fact that mobile viral marketing is tremendously attractive for marketers but neglected by academic research. We provided four standard types and identified eight factors assuring the success of mobile viral marketing. With clear reflections of their significance in different standard types we structure the relationship and developed a success factor framework. This framework supports marketers in defining as well as evaluating mobile viral strategies. Following these straightforward and intuitive guidelines increases the likelihood of high viral diffusion of mobile viral content. Typically, not all of the above mentioned factors are necessary to make mobile viral marketing successful. However, the probability of success increases with the number of success factors considered.

On issues of future research, the standard types offer some interesting research avenues: First, further research on the standard type Motivated Evangelism, especially its instance mobile community, is needed. Interesting research topics are the content of customers' articulation and the motivation behind the decision to engage in such communication. Another question is how marketers can use mobile communities to promote and distribute products and services. Second, this type as well as the type Signaling Use, Group Membership deserve closer examination in the context of diffusion theory. As both deal with network externalities, it may be valuable to know what motivates early adopters to actively persuade recipients to also try or passively disseminate such services. Third, considering the standard types Targeted Recommendation and Awareness Creation, Benefits Signaling, it may be very enriching to analyze motives, reactions, and behaviors of those who forward and receive mobile viral content, especially mobile ads. In addition, on issues of future research, the success factors offer some interesting research avenues: For instance, the success factor initial contact deserves closer examination. Thus, fourth, an extremely interesting next step for future research could be to profile types of viral participants. If detailed behavioral and psychographic profiles could be developed, marketers would be able to target those valuable mobile viral mavens more easily. Of particular value would be a large-scale psychographic segmentation study. Our future research will begin to tackle these challenges.

With large technological and cultural changes looming on the horizon, we see clear evidence that for the advertising and mobile industry mobile viral 
Pousttchi, K.; Wiedemann, D. G.: Success Factors in Mobile Viral Marketing: A Multi-Case Study Approach. Proceedings of the 6th International Conference on Mobile Business (ICMB 2007). IEEE Computer Society Press. Toronto, Ontario, Canada 2007.

marketing will be an increasingly important force in the near future.

Table 2. Typical case study examples

\begin{tabular}{|c|c|}
\hline Type & ompany (campaign name) and description \\
\hline 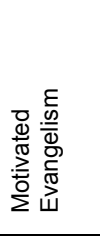 & $\begin{array}{l}\text { Zlango: } \\
\text { The communication service enables creation and sending } \\
\text { of messages made up of over } 200 \text { icons to express words, } \\
\text { concepts, or feelings. Communicators as well as recipients } \\
\text { are required to download the mobile application to use the } \\
\text { service. Network externalities are high as both and others } \\
\text { users benefit from a wider diffusion of the service, and } \\
\text { active persuasion by early adopters is common. }\end{array}$ \\
\hline 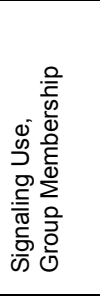 & $\begin{array}{l}\text { Paybox: } \\
\text { The mobile payment procedure enabled among others } \\
\text { money transfers between customers. When a user sent } \\
\text { money to an unregistered user, he or she was able to } \\
\text { receive the money only after signing up for the mobile } \\
\text { payment procedures. Network externalities are high as } \\
\text { both and other users benefit from a wider diffusion of the } \\
\text { service, and persuasion by communicators is passive as } \\
\text { the recommendation was done by an SMS from paybox } \\
\text { that informed about the service. }\end{array}$ \\
\hline 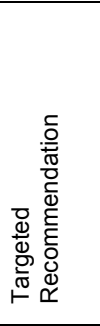 & $\begin{array}{l}\text { Adidas (+10 campaign): } \\
\text { Initial contacts were briefed on the commercial WAP portal } \\
\text { by advertisement on a mobile network operator portal. } \\
\text { Communicators use a send-to-a-friend-option and } \\
\text { recommend the commercial WAP portal by entering his or } \\
\text { her name as well as the name and the MSISDN of } \\
\text { recipient who receives a WAP Push leading to the WAP } \\
\text { portal. Network externalities are low as both do not benefit } \\
\text { from a wider diffusion of the WAP portal, and active } \\
\text { persuasion by communicators is common as they have to } \\
\text { choose the recipients. }\end{array}$ \\
\hline 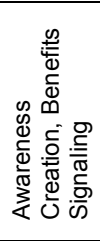 & $\begin{array}{l}\text { L'Oréal (Mobile Kiss): } \\
\text { Initial contacts were briefed on the sound greeting cards by } \\
\text { Push SMS. Communicators sent an SMS with their name, } \\
\text { the selected a sound card indicated by "F" or "M" according } \\
\text { their sex and the recipient's MSISDN to L'Oréal. The } \\
\text { company sent the sound greeting card and afterwards an } \\
\text { SMS with information about the communicator and the } \\
\text { forwarding mechanism to receivers. }\end{array}$ \\
\hline
\end{tabular}

\section{References}

[1] H.H. Bauer, S.J. Barnes, T. Reichardt, and M.M. Neumann, "Driving Consumer Acceptance of Mobile Marketing: A Theoretical Framework and Empirical Study", Journal of Electronic Commerce Research, 6 (3), 2005, pp. 181-192.

[2] A.B. Bondi, "Characteristics of scalability and their impact on performance", Proceedings of the 2nd International Workshop on Software and Performance, Ontario, Canada, 2000, pp. 195-203.

[3] P. Barwise and C. Strong, "Permission-based Mobile Advertising", Journal of Interactive Marketing, 16 (1), 2002, pp. $14-24$.

[4] CE Europe, "This is T-Virus.UK”, http://www.t-virus.co.uk/, 2007.

[5] Davis, F., "Perceived usefulness, perceived ease of use, and user acceptance of information technology", MIS Quarterly, 13 (3), 1989, pp. 319-340.
[6] Economides, N., "The Economics of Networks", International Journal of Industrial Organization, 14 (2), pp. 673-699.

[7] N. Economides and C. Himmelberg, "Critical Mass and Network Evolution in Telecommunications", G. Brock (Ed.) Toward a Competitive Telecommunications Industry: Selected Papers from the 1994 Telecommunications Policy Research Conference, University of Maryland, College Park, MD, 1995, pp. 31-42.

[8] K, Eisenhardt, "Building Theories from Case Study Research", Academy of Management Review, 14 (4), 1989, pp. $532-550$.

[9] R. Grunder, "Das aktuelle Stichwort - Viral Marketing", Wirtschaftswissenschaftliches Studium, 32 (9), 2003, pp. 539541.

[10] S. Helm, "Viral Marketing - Establishing Customer Relationships by 'Word-of-mouse"”, Electronic Markets, 10 (3), 2000, pp. 158-161.

[11] Intuitive Media and New Media Age, Kids Go Mobile Ownership and Use of Mobile Phones By Children aged 6 to 13, http://intuitivemedia.com/ie.html, 2006.

[12] I-play, "I-play Outlines Collective Industry Action Required for Mobile Gaming Market to Reach True Potential", press release, June 6, 2005.

[13] M.L. Katz and C. Shapiro, "Network Externalities, Competition, and Compatibility", American Economic Review 75 (3), 1985, pp. 424-440.

[14] Lawler, E.E., III., "The Strategic Design of Reward Systems", in C. Fombrun, N. Tichy, and M. Devanna (Eds.), Strategic Human Resource Management. Wiley, New York, 1984, pp. 127-147.

[15] M. Leppäniemi, J. Sinisalo, and H. Karjaluoto, “A Review of Mobile Marketing Research", International Journal of Mobile Marketing, 1 (1), 2006, pp. 30-42.

[16] MindMatics, "T-Mobile und tele.ring verschenken mit MindMatics digitalen WM-Rasen im Handy-Portal“, press release, July 3, 2006.

[17] A. Mahler and E.M. Rogers, "The Diffusion of Interactive Communication Innovations and the Critical Mass: The Adoption of Telecommunications Services by German Banks", Telecommunications Policy, 23 (10-11), 1999, pp. 719-740.

[18] S. Okazaki, "New Perspectives on M-Commerce Research", Journal of Electronic Commerce Research, 6 (3), 2005, pp. 160164.

[19] M. Pagani, "Determinants of adoption of third generation mobile multimedia services", Journal of Interactive Marketing, 18 (3), 2006, pp. 46-59.

[20] J.E. Phelps, R. Lewis, L. Mobilio, and D. Perry, "Viral Marketing or Electronic Word-of-Mouth Advertising: Examining Consumer Responses and Motives to Pass Along 
Pousttchi, K.; Wiedemann, D. G.: Success Factors in Mobile Viral Marketing: A Multi-Case Study Approach. Proceedings of the 6th International Conference on Mobile Business (ICMB 2007). IEEE Computer Society Press. Toronto, Ontario, Canada 2007.

Email", Journal of Advertising Research, 45 (4), 2004, pp. 333348.

[21] K. Pousttchi and D.G. Wiedemann, "Contribution to Theory Building for Mobile Marketing: Categorizing Mobile Marketing Campaigns through Case Study Research", Proceedings of the International Conference on Mobile Business (ICMB 2006), Copenhagen, Denmark 2006.

[22] Rosen, E. The Anatomy of Buzz, Doubleday, New York, 2000 .

[23] Rogers, E.M., Diffusion of Innovation, Free Press, New York, 2003.

[24] M.R. Subramani and B. Rajagopalan, "Knowledge-Sharing and Influence in Online Social Networks via Viral Marketing", Communications of ACM, 46 (12), 2003, pp. 300-307.

[25] Shapiro, C. and Varian, H.R., Information rules, Harvard Business School Press, Boston, MA, 1998.

[26] Wilson, R.F., "The Six Simple Principles of Viral Marketing”, Web Marketing Today, 70, 2000.

[27] D.G. Wiedemann, "Exploring the Concept of Mobile Viral Marketing through Case Study Research", Proceedings of the 2nd conference of Mobilität und mobile Informationssysteme (MMS 2007), Aachen, Germany 2007, pp. 49-60.

[28] D.G. Wiedemann and S. Marini, "Entwicklungen im Bereich Mobile Advertising aus der Sicht von Experten Ergebnisse der Expertenbefragung MM1", Pousttchi, K. (Ed.), Studienpapiere der Arbeitsgruppe Mobile Commerce, Bd. 1, Augsburg, 2006, pp. 1-49.

[29] Zwicky, F., Entdecken, Erfinden, Forschen im Morphologischen Weltbild. Knaur-Droemer Verlag, Munich, 1966. 